\title{
Concept of Human Resources Development to Improve Teacher Performance: Multi-Case Study
}

\author{
*M B Harahap ${ }^{1}$, M V Roesminingsih ${ }^{1}$, Mudjito ${ }^{1}$ \\ ${ }^{1}$ Doctoral Program of Educational Management, Universitas Negeri Surabaya, Surabaya Indonesia
}

\begin{tabular}{|c|c|}
\hline Article Info & ABSTRACT \\
\hline $\begin{array}{l}\text { Article history: } \\
\text { Received November 15, } 2020 \\
\text { Revised December 12, 2020 } \\
\text { Accepted December 26, } 2020 \\
\text { Available Online December 28, } \\
2020\end{array}$ & $\begin{array}{l}\text { This study aims to analyze the concept of Human Resource } \\
\text { Development carried out by schools in improving the performance of } \\
\text { teaching staff at Elementary School Muhammadiyah of } 1 \text { Jember and } \\
\text { Al Baitul Amien of } 1 \text { Jember. This research method uses a qualitative } \\
\text { approach with a multi-case study design. The multi-case study used } \\
\text { in this study uses two research sites. Data collection techniques in this } \\
\text { study used participant observation, documentation, and interviews. }\end{array}$ \\
\hline $\begin{array}{l}\text { Keywords: } \\
\text { Human Resource Development } \\
\text { Multi Case Studies } \\
\text { Performance }\end{array}$ & $\begin{array}{l}\text { Based on the research conducted, it can be concluded that the concept } \\
\text { of the human resource development program carried out by these } \\
\text { schools to improve the quality of teacher performance, namely: (1) } \\
\text { increasing the abilities, skills, attitudes, and responsibilities of } \\
\text { educators (teachers) to be more effective and efficient, (2) optimizing } \\
\text { human resource development as much as possible by delegating to } \\
\text { educators (teachers), and (3) striving to improve education quality by } \\
\text { recommending educators (teachers) to take further studies to a higher } \\
\text { level. There is no multi-case study research in improving the } \\
\text { performance of students. }\end{array}$ \\
\hline
\end{tabular}

https://doi.org/10.46627/silet

\section{INTRODUCTION}

Education's characteristics are universal or comprehensive - both in attitude and education space (David, 2014). Continuous education never stops and gives up from time to time, so that the integration of teaching and skills continues to be developed (Tam et al., 2018). Education has its existence in building a country's civilization. It is a good indication that developed countries have a high level of awareness of productive human resources (Nadarajah et al., 2012; Figueiro \& Raufflet, 2015). Education is one of the essential prerequisites for the continuity of education to keep developing with the times, resulting in free human thinking (Prahani et al., 2020) in harmonizing the times. These developments are both academic and non-academic (Bair \& Bair, 2011; Austin \& Sorcinelli, 2013), both in natural resources and managing their supporting infrastructure (Nadarajah et al., 2012; Berryman \& Sauve, 2016; Barth et al., 2007).

Education requires superior human resources (Saw \& Watana, 2020). Human resources that can have a good and active performance will influence an institution or organization (Vosloban, 2012). Educational organizations and institutions need human resources who can continue to develop with the changing times. Collaboration between employees, in this case, is needed (Amundsen \& Wilson, 2012). All elements of the members in the agency need to improve performance or facilities continuously. Real superior schools are generally built jointly by all school members' elements, not solely by education authorities (Stes et al., 2010).

At this time, to create a good or superior school, it must be designed and planned with an excellent curriculum (Setiawan, 2020) and also served by educators (teachers) who are committed and of high quality (Wijaya et al., 2016; Mangkunegara, 2011; Tenggala, 2013). Real superior schools can be achieved if all of the school's resources can be utilized optimally (Talan \& Tyagi, 
2020; Bearman et al., 2012; Zuhro, 2015). It means that all elements of the school, including school principals, administrative staff, school curriculum developers, teachers, and school caretakers, must be directly and thoroughly involved (Irmayani et al., 2018) because all these resources will create an excellent and good school atmosphere, able to make an adequate or superior institution/school (Omebe, 2014; Septi, 2017).

Based on the pre-field results and information obtained at the Muhammadiyah 1 Jember Elementary School and the Al Baitul Amien 1 Jember Elementary School, information was obtained and several human resource development phenomena in both schools. The information obtained by the phenomenon is that some differences or limitations appear in the Muhammadiyah 1 Jember Elementary School and the Al Baitul Amien 1 Jember Elementary School regarding student achievement which is fairly good based on data while the activities, creativity, and innovation of educators (teachers) in upgrading their knowledge are lacking. . In this case, the two schools have the same problems regarding human resources at the primary school education level.

One of the problems with teaching resources in these schools can be caused by inadequate leadership processes in learning and school management. For decentralization and educational autonomy to be successful, the principal's leadership must be maximally and continuously empowered (Omebe, 2014; Kumaedi et al., 2010). The empowerment of principal leadership in question is to increase functional abilities so that teachers as educators play a role by their primary duties and functions and the authority and purpose of their duties (Wijaya \& Nyoto, 2016; Krismiyati, 2017; Suharto, 2017).

The activities, creativity, and innovation of the less developed students (teachers) can be seen through the learning carried out by the teacher who still often uses conventional learning, and some school activities are not running or have not been implemented such as workshop, seminars or training, or other activities that should be able to improve experience and knowledge of students. Based on the conditions of the problem, it is not by the theory of opening education. Competent educational institutions must be oriented towards forming competent human beings or students (UPI Lecturer Team, 2012). In solving the problem, it is indispensable to research to obtain more accurate information about Human Resource Development, especially on improving educators' performance as teachers in both schools to improve and improve performance optimally at Muhammadiyah 1 Jember Elementary School and Al Elementary School Baitul Amien 1 Jember.

\section{RESEARCH METHOD}

\section{General Background}

This study uses a qualitative approach to the type of evaluation research. When researchers have obtained information from researchers (students), then an evaluation analysis is carried out on the information or data obtained. The research design used a descriptive multi-case study, namely the process of making comparisons between two or more research sites. Two research sites were used, namely the elementary school level of education. The research location is in a different location so that it has different criteria, but there is no possibility of a similarity in the menus of the two schools.

\section{Sample/Participant}

The sample in this study was the board of the foundation as policymakers at the Muhammadiyah 1 Jember Elementary School and the Al Baitul Amien 1 Jember Elementary School as the stakeholders, as well as the Human Resources (HR) managers at the Muhammadiyah 1 Jember Elementary School and the Al Baitul Amien 1 Jember Elementary School. The sample of this study included: principals, curriculum representatives, vice principals, teachers, and students of both schools. 


\section{Instrument and Procedures}

Researchers carry out data collection by visiting subjects or informants and conducting interviews to obtain complete data and information. Data collection was carried out using participatory observation techniques, structured and in-depth interviews, and documentation. Research with a qualitative approach was conducted with four criteria for data validity: 1) Credibility, 2) Transferability, 3) Dependability, and 4) Confirmability. In Credibility, the researcher made prolonged observations to obtain relevant information and checked the correctness of the information regarding the management of student resources at Muhammadiyah 1 Jember Elementary School and Al Baitul Amien 1 Elementary School. The transferability process is a process where researchers determine standards in finding the same topic and harmonious than the results of information regarding students' human development in the two schools are described in detail and tune. The dependability process is the audit process of the fundamental research, wherein in this process, the researcher conducts discussions with experts in the field. Finally, the confirmability process is where the results of this study have been mutually agreed upon by experts.

\section{Data Analysis}

The data analysis process is carried out in several steps, namely

1. Data condensation (the process of selecting, simplifying, and transforming data that is close to the overall data, both interviews, documents, and observations regarding the development of student resources),

2. Data presentation (a collection of information obtained by researchers allows a conclusion),

3. Drawing conclusions and verification.

\section{RESULT AND DISCUSSION}

A. The concept of Human Resources Development was carried out by the Elementary School Muhammadiyah of 1 Jember in improving the performance of educators.

An overview of the concept of human resource development carried out by schools in improving the performance of teaching staff at Elementary School Muhammadiyah of 1 Jember can be seen in Table 1.

Table 1. Human Resources Development Activities conducted by Educators at Elementary School Muhammadiyah of 1 Jember

\begin{tabular}{|c|c|c|c|c|}
\hline No & Name of activity & Topic & Time and Place & Level \\
\hline 1 & $\begin{array}{l}\text { Education and } \\
\text { training }\end{array}$ & $\begin{array}{l}\text { Educational and Review } \\
\text { of Graduate } \\
\text { Competency Standards }\end{array}$ & $\begin{array}{l}\text { 25-26 January } 2018 \text { at } \\
\text { Elementary School of } \\
\text { Muhammadiyah } 1 \\
\text { Jember }\end{array}$ & $\begin{array}{l}\text { Local } \\
\text { Intern Elementary } \\
\text { School of } \\
\text { Muhammadiyah } \\
\text { 1 Jember }\end{array}$ \\
\hline 2 & $\begin{array}{l}\text { Education and } \\
\text { Training }\end{array}$ & $\begin{array}{l}\text { Head of Library } \\
\text { Training }\end{array}$ & $\begin{array}{l}\text { 8-17 September } 2018 \\
\text { At the Regional } \\
\text { Library of Jember } \\
\text { Regency }\end{array}$ & Districts \\
\hline 3 & $\begin{array}{l}\text { Education and } \\
\text { Training }\end{array}$ & $\begin{array}{l}\text { Mathematics teacher } \\
\text { education and training }\end{array}$ & $\begin{array}{l}\text { 5-7 August } 2019 \\
\text { Hotel Campi Surabaya }\end{array}$ & Province \\
\hline 4 & Seminar & $\begin{array}{l}\text { International Seminar } \\
\text { on Educational } \\
\text { Concepts in Finland }\end{array}$ & $\begin{array}{l}17 \text { February } 2020 \\
\text { Elementary School } \\
\text { Muhammadiyah of } 5 \\
\text { Jakarta }\end{array}$ & International \\
\hline 5 & Workshop & $\begin{array}{l}\text { Basic Literacy } \\
\text { Workshop }\end{array}$ & $\begin{array}{l}\text { 10-14 November } 2018 \\
\text { Harris Hotel Malang }\end{array}$ & National \\
\hline
\end{tabular}




\begin{tabular}{|c|c|c|c|c|}
\hline 6 & Workshop & $\begin{array}{l}\text { Basic Literacy } \\
\text { Development in Early } \\
\text { Grades }\end{array}$ & $\begin{array}{l}\text { December 14, } 2019 \\
\text { East Java } \\
\text { Muhammadiyah } \\
\text { Regional Leadership } \\
\text { Hall }\end{array}$ & Province \\
\hline 7 & $\begin{array}{l}\text { Teacher Working } \\
\text { Group }\end{array}$ & $\begin{array}{l}\text { Similarity of Perceptions } \\
\text { for low grade Al Islam } \\
\text { teachers (grades } 12 \text { and } \\
\text { 3) Material: Wudu } \\
\text { method }\end{array}$ & $\begin{array}{l}\text { July 29, } 2019 \\
\text { Muhammadiyah } \\
\text { Elementary School } \\
\text { Hall of 1 Jember }\end{array}$ & $\begin{array}{l}\text { Local } \\
\text { Intern Elementary } \\
\text { School } \\
\text { Muhammadiyah } \\
\text { of } 1 \text { Jember }\end{array}$ \\
\hline
\end{tabular}

From the presentation of the Table 1, it can be seen that several activities indicate the existence of human resource development activities carried out by educators at Elementary School Muhammadiyah of 1 Jember. The table above shows that the concept of human resource development in Muhammadiyah 1 Jember Elementary School is already running. The concept of human resource development applied by the Muhammadiyah 1 Jember Elementary School refers to a development theory that is more directed at improving the quality of education, perfecting and maximizing educational functions.

Continuous refinement of the system and continuously is a development step that needs to be carried out by educational institutions and schools (Irmayani et al, 2018). Therefore, the program that must and needs to be carried out is the professional development of educators with pre-service and in-service education programs. Elementary School Muhammadiyah of 1 Jember has a superior program that is implemented. with this School shows a commitment to the development of educator resources. Through this superior program to improve and develop the competence and professionalism of educators.

This was revealed by the Principal of Elementary School Muhammadiyah 1 Jember that:

"Regarding the success of professional development of educators, I always give confidence by giving all Deputy Principals and teachers the responsibility to implement each education quality standard".

W.03/BMS/HEAD/MUH1JBR/1/2018

\section{Single case study findings:}

The research findings on the first site are related to the concept of developing Human Resources carried out by schools in improving the performance of teaching staff at Elementary School Muhammadiyah of 1 Jember. Based on the explanation of research data that has been previously stated, the researcher found the findings of research notes related to the concept of human resource development at Elementary School Muhammadiyah of 1 Jember, which are presented in Table 2.

Table 2. The concept of human resource development carried out by schools in improving the performance of teaching staff at Elementary School Muhammadiyah of 1 Jember

\begin{tabular}{|c|c|c|}
\hline No & Findings & Findings Notes \\
\hline 1 & $\begin{array}{l}\text { Educator professional } \\
\text { development in recruitment }\end{array}$ & $\begin{array}{l}\text { (1) Recruitment is going well } \\
\text { (2) Improvement of education quality standards }\end{array}$ \\
\hline 2 & $\begin{array}{l}\text { Educator development program } \\
\text { in recruitment }\end{array}$ & $\begin{array}{l}\text { (1) Program implementation is carried out in a } \\
\text { flexible manner } \\
\text { (2) Increase the potential and supporting factors } \\
\text { in developing educator skills } \\
\text { (3) Increasing the skills of educators and } \\
\text { teaching staff }\end{array}$ \\
\hline 3 & $\begin{array}{l}\text { Regulations concerning the } \\
\text { development of educators in } \\
\text { transfer and promotion }\end{array}$ & $\begin{array}{l}\text { (1) Written educator implementing regulations } \\
\text { (2) Regulations on increasing teaching staff are } \\
\text { binding and for all }\end{array}$ \\
\hline
\end{tabular}


The concept of human resource development for teaching staff at Elementary School Muhammadiyah of 1 Jember was carried out in several steps, based on interviews with school principals including program preparation, determination of needs, targeting, program determination, identification of learning principles, and program implementation. According to research by Nadarajah et al (2012) which states that educational institutions have highperformance staff and a consistent work program that will continue to develop human resources in these institutions. Planning and designing a good curriculum in learning will improve the quality of my human resources for educators (Wijaya et al, 2016; Mangkunegara, 2011; Tenggala, 2013).

\section{B. The concept of Human Resource Development carried out by schools in improving the performance of teaching staff at Elementary School Al Baitul Amien of 1 Jember}

The concept of human resource development for teaching staff at Elementary School Al Baitul Amien of 1 Jember is basically not much different from schools in general, carried out in several steps, based on interviews with school principals, including:

"Several potentials and supporting factors as well as various possibilities that can be pursued in the human resource development program for educators. By improving the skills of educators through training workshops, seminars, and further studies for all educators with the pension rules for employees aged 58 and teachers 60 years. W.02/BMS/HEAD/ALAMIN1JBR/8/2019

In the development program, targets, policies, procedures, budgets, participants, curriculum, and timing for implementation are determined and are informed openly to all educators. To see an overview of the concept of human resource development carried out by schools in improving the performance of teaching staff at Elementary School Al Baitul Amien of 1 Jember, it can be seen in Table 3.

Tabel 3. Human Resource Development Activities for Educators at Elementary School Al Baitul Amien of 1 Jember

\begin{tabular}{|c|c|c|c|c|}
\hline No & Name of activity & Topic & Time and Place & Level \\
\hline 1 & $\begin{array}{l}\text { Education and } \\
\text { training }\end{array}$ & $\begin{array}{l}\text { Review of } \\
\text { Graduate } \\
\text { Competency } \\
\text { Standards }\end{array}$ & $\begin{array}{l}\text { 21-22 January } 2018 \text { at } \\
\text { Elementary School Al } \\
\text { Baitul Amien of } 1 \text { Jember }\end{array}$ & $\begin{array}{l}\text { Local } \\
\text { Intern Elementary } \\
\text { School Al Baitul } \\
\text { Amien of } 1 \text { Jember }\end{array}$ \\
\hline 2 & $\begin{array}{l}\text { Education and } \\
\text { training }\end{array}$ & $\begin{array}{l}\text { Education and } \\
\text { training for the } \\
\text { Head of Library }\end{array}$ & $\begin{array}{l}\text { 8-17 September } 2018 \\
\text { At the Regional Library of } \\
\text { Jember Regency }\end{array}$ & Districts \\
\hline 3 & $\begin{array}{l}\text { Education and } \\
\text { training }\end{array}$ & $\begin{array}{l}\text { Mathematics } \\
\text { teacher education } \\
\text { and training }\end{array}$ & $\begin{array}{l}\text { 5-7 August } 2019 \\
\text { Hotel Campi Surabaya }\end{array}$ & Province \\
\hline 4 & Seminar & $\begin{array}{l}\text { National Seminar } \\
\text { on Educational } \\
\text { Challenges in the } \\
\text { Industrial era } 4.0 \\
\end{array}$ & $\begin{array}{l}17 \text { February } 2020 \\
\text { Hotel Aston Jember }\end{array}$ & National \\
\hline 5 & Workshop & $\begin{array}{l}\text { Classroom Action } \\
\text { Research Writing } \\
\text { Workshop }\end{array}$ & $\begin{array}{l}\text { 10-14 November } 2018 \\
\text { Hotel Ibis Surabaya }\end{array}$ & National \\
\hline 6 & $\begin{array}{l}\text { Teacher } \\
\text { Working Group }\end{array}$ & $\begin{array}{l}\text { Preparation of } \\
\text { lesson plans }\end{array}$ & $\begin{array}{l}\text { January 29, } 2019 \\
\text { Elementary School Al } \\
\text { Baitul Amien of } 1 \text { Jember }\end{array}$ & $\begin{array}{l}\text { Local } \\
\text { Intern Elementary } \\
\text { School Al Baitul } \\
\text { Amien of } 1 \text { Jember }\end{array}$ \\
\hline
\end{tabular}

The process of developing human resources for educators at Elementary School Al Baitul Amien of 1 Jember is compiled for long, medium, and short term programs and is generally 
programmed at the beginning of the learning year with various considerations related to needs, facilities, implementation, and budget.

According to what was conveyed by the Principal of Elementary School Al Baitul Amien of 1 Jember, namely:

"Efforts to develop human resources for educators by determining needs, determining needs are made to know and overcome various new challenges and challenges that will come. So development will only be carried out if the need is needed and in determining the need there are several parties involved including the principal, head of administration, deputy head of school as well as educators and education personnel "W.2/BMS/HEAD/ ALAMIN1JBR/8/2019.

In this case, the development will only be carried out if the need is needed and in determining needs there are several parties involved including the principal, the head of administration, the deputy principal of the school, and the educators. No matter how ideal the development objectives, the amount of available costs always demands the planners the necessary adjustments, so that the programs offered remain affordable.

Based on the implementation of these programs according to the Principal of Elementary School Al Baitul Amien of 1 Jember, stated that:

"Facilities are the most important thing in program utilization. Apart from costs, facilities are an aspect that also influences the planning and implementation process of human resource development for educators and educational personnel. What is meant by facilities are Learning Facilities (library, laboratory, media, tools, practices, books, and others). supporting facilities (means of transportation, printing equipment, and others. "W.3.1/BMS/HEAD/ALAMIN1JBR /1/2018.

This means that the more complete the facilities you have, the easier the planning and implementation of human resource development activities for educators and educational personnel will be. Some facilities such as information technology. Technological facilities will greatly assist educators in facilitating learning activities (Lince, 2016 Irmayani et al, 2018).

\section{Single case study findings:}

Research findings on the second site are related to the concept of human resource development carried out by schools in improving the performance of teaching staff at Al Baitul Amien 1 Jember Elementary School. Based on the explanation of research data that has been previously stated, the researcher found the findings of research notes related to the concept of human resource development at Elementary School Al Baitul Amien of 1 Jember, which are presented in Table 4.

Table 4. The Concept of Human Resource Development Carried Out by Schools in Improving the Performance of Teaching Staff at Elementary School Al Baitul Amien of 1 Jember

\begin{tabular}{|c|c|c|}
\hline No & Findings & Findings Notes \\
\hline 1 & $\begin{array}{l}\text { Educator professional } \\
\text { development in recruitment }\end{array}$ & $\begin{array}{l}\text { (1) It is organized and runs according to the rules } \\
\text { (2) Improvement of education quality standards } \\
\text { using a program of skills improvement programs }\end{array}$ \\
\hline 2 & $\begin{array}{l}\text { Educator development program } \\
\text { in recruitment }\end{array}$ & $\begin{array}{l}\text { (1) Program implementation is carried out } \\
\text { periodically and in a planned manner } \\
\text { (2) Increase the potential and supporting factors in } \\
\text { skills improvement training } \\
\text { (3) Increasing the skills of educators and teaching } \\
\text { staff through various programs }\end{array}$ \\
\hline 3 & $\begin{array}{l}\text { Regulations concerning the } \\
\text { development of educators in } \\
\text { transfer and promotion }\end{array}$ & $\begin{array}{l}\text { (1) The implementing regulations for educators are } \\
\text { implemented and binding } \\
\text { (2) Regulations concerning the improvement of } \\
\text { teaching staff regulates skill enhancement and } \\
\text { recruitment rules until discharge/retirement }\end{array}$ \\
\hline
\end{tabular}




\section{Final Findings Both Concepts:}

The concept of developing human resources, which is implemented by schools to improve the performance of educators (teachers) at Elementary School Muhammadiyah of 1 Jember and the Elementary School Al Baitul Amien of 1 Jember, namely first, (a) Increase abilities, skills, attitudes and responsibilities educators (teachers) to be more effective and efficient in achieving program goals and school goals through regular and periodic and continuous religious guidance. In line with research from Mukolwe et al (2017), it is stated that the existence of the management of human resources increases the performance and skills of educators so that there is a significant positive effect.

The Second, b) optimizing human resource development as much as possible by delegating to educators (teachers) to increase competence through skills and knowledge development activities, either independently or institutionally. The concept of developing skills and knowledge in improving the performance of educators (teachers) in both schools is carried out through various supporting activities such as workshops and education and training, which must be ongoing and routinely carried out to improve the quality of educators (teachers), due to teaching staff (teachers). is an important and complex component that must receive top priority, because to get educators (teachers) who are competent and qualified, harmonious and effective cannot be the same as easily procuring and placing machines in one place without routine maintenance, and Educators are not machines that are employed continuously, so that teaching staff (teachers) need to get special attention, as an activity step to pay special attention to educators (teachers), then refresher is carried out through workshops and training activities so that the quality and quantity of teaching personnel teacher) according ai with the needs of institutions or schools, more effective and efficient to support the achievement of school goals. In line with research from Suharto (2017) in hypothesis testing, it shows that supervision and training have a positive effect on performance. And also improve the quality of the workforce (Suhardan, 2014).

The third, c) strive to improve the quality of education by recommending educators (teachers) to take further studies to a higher level or for educators (teachers) who are not linear, schools provide education for educators (teachers) according to the field of work they can support. provide opportunities and recommendations to take part in an equalization program, this is done in increasing the academic knowledge and skills of educators (teachers). To improve the quality of education, the professionalism of educators needs to be improved using further study (Irmayani et al, 2018; Fahrudin 2015; Maamarah, 2016).

In general, the concept of the human resource development program carried out by the two schools in maintaining the quality and improving the performance of educators (teachers) starts from an analysis of the needs of teaching staff (teachers), recruitment (recruitment), candidate selection, orientation and induction that has been planned and well structured, thus helping in the process of achieving educational goals in both schools. In line with research from Irmayani 2018, it was stated that in developing Elementary School Puri teaching resources, it was carried out by management starting from the admission of new students, the recruitment process, implementing activities to the end of the activity implementation program. Based on the analysis above, the findings of case 1 and case 2 can be tabulated along with the final findings of the two schools in the table below:

Table 6. Multi Case Study Of Human Resource Development Concept in Both Schools

\begin{tabular}{|c|c|c|c|c|c|}
\hline No & Findings & & $\begin{array}{c}\text { Case Findings } 1 \\
\text { (Elementary School } \\
\text { Muhammadiyah of } 1 \\
\text { Jember) }\end{array}$ & $\begin{array}{c}\text { Case Findings } 2 \\
\text { (Elementary School Al } \\
\text { Baitul Amien of } 1 \text { Jember) }\end{array}$ & Final Findings \\
\hline 1 & $\begin{array}{l}\text { Educator } \\
\text { professional } \\
\text { development in } \\
\text { recruitment }\end{array}$ & $\begin{array}{l}\text { (1) } \\
\text { (2) }\end{array}$ & $\begin{array}{l}\text { Recruitment is going } \\
\text { well } \\
\text { Improvement of } \\
\text { education quality } \\
\text { standards }\end{array}$ & $\begin{array}{l}\text { (1) It is organized and runs } \\
\text { according to the rules } \\
\text { (2) Improvement of } \\
\text { education quality } \\
\text { standards using a }\end{array}$ & $\begin{array}{l}\text { Increase the } \\
\text { abilities, skills, } \\
\text { attitudes, and } \\
\text { responsibilities of } \\
\text { educators }\end{array}$ \\
\hline
\end{tabular}




\begin{tabular}{|c|c|c|c|c|c|c|c|}
\hline & & & & & $\begin{array}{l}\text { program of skills } \\
\text { improvement programs }\end{array}$ & \multirow{3}{*}{$\begin{array}{l}\text { (2) } \\
\text { (3) }\end{array}$} & \multirow{3}{*}{$\begin{array}{l}\text { (teachers) to be } \\
\text { more effective and } \\
\text { efficient } \\
\text { Optimizing human } \\
\text { resource } \\
\text { development as } \\
\text { much as possible } \\
\text { by delegating to } \\
\text { teaching staff } \\
\text { (teachers) } \\
\text { Strive to improve } \\
\text { the quality of } \\
\text { education by } \\
\text { recommending } \\
\text { educators } \\
\text { (teachers) to attend } \\
\text { further studies to a } \\
\text { higher level. }\end{array}$} \\
\hline 2 & $\begin{array}{l}\text { Educator } \\
\text { development } \\
\text { program in } \\
\text { recruitment }\end{array}$ & (2) & $\begin{array}{l}\text { Program } \\
\text { implementation is } \\
\text { carried out in a } \\
\text { flexible manner } \\
\text { Increase the potential } \\
\text { and supporting } \\
\text { factors in developing } \\
\text { educator skills } \\
\text { Increasing the skills } \\
\text { of educators and } \\
\text { teaching staff }\end{array}$ & (3) & $\begin{array}{l}\text { Program } \\
\text { implementation is } \\
\text { carried out periodically } \\
\text { and in a planned } \\
\text { manner } \\
\text { Increase the potential } \\
\text { and supporting factors } \\
\text { in skills improvement } \\
\text { training } \\
\text { Increasing the skills of } \\
\text { educators and teaching } \\
\text { staff through various } \\
\text { programs }\end{array}$ & & \\
\hline 3 & $\begin{array}{l}\text { Regulations } \\
\text { concerning the } \\
\text { development of } \\
\text { educators in } \\
\text { transfer and } \\
\text { promotion }\end{array}$ & (2) & $\begin{array}{l}\text { Written educator } \\
\text { implementing } \\
\text { regulations } \\
\text { Regulations on } \\
\text { increasing teaching } \\
\text { staff are binding and } \\
\text { for all }\end{array}$ & (1) & $\begin{array}{l}\text { The implementing } \\
\text { regulations for } \\
\text { educators are } \\
\text { implemented and } \\
\text { binding } \\
\text { Regulations concerning } \\
\text { the improvement of } \\
\text { teaching staff regulates } \\
\text { skill enhancement and } \\
\text { recruitment rules until } \\
\text { discharge/retirement }\end{array}$ & & \\
\hline
\end{tabular}

\section{Cross-site findings of the concept of Human Resource Development carried out by schools in improving the performance of teaching staff at Elementary School Muhammadiyah of 1 Jember and Elementary School Al Baitul Amien of 1 Jember.}

Referring to the results of individual case studies for each institution in the two schools, namely the Elementary School Muhammadiyah of 1 Jember and the Elementary School Al Baitul Amien of 1 Jember, a comparison is found in Figure 1.

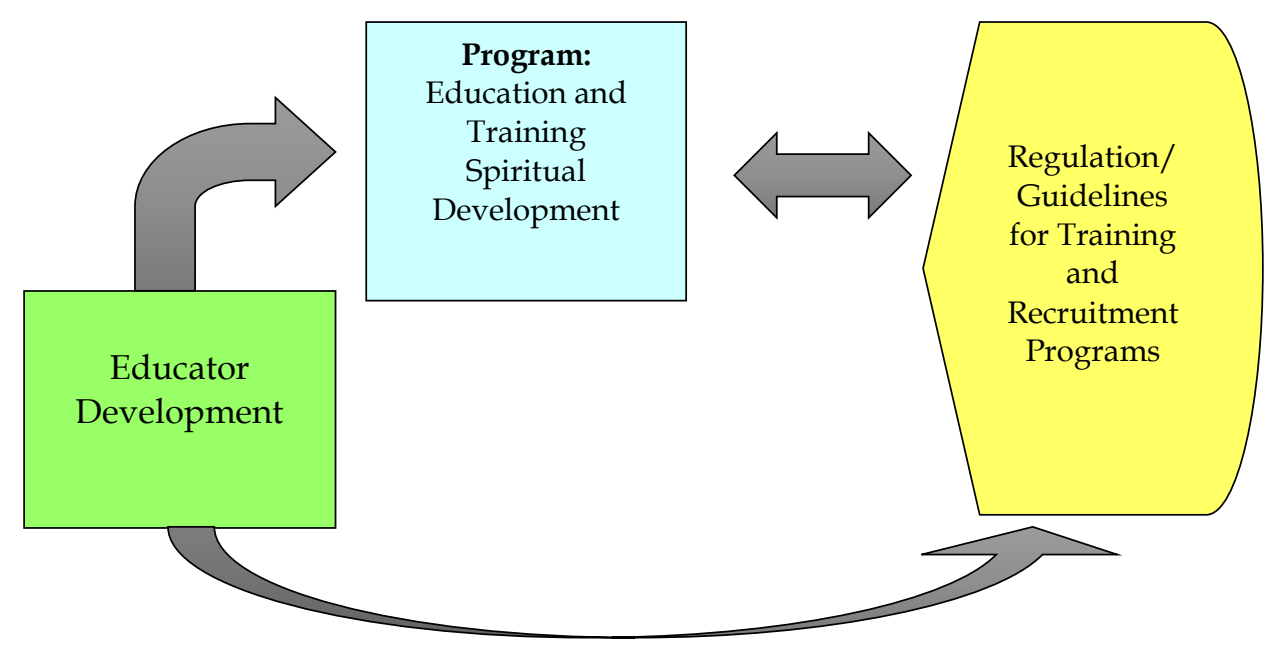

Figure 1. Educator Development Program

From the Figure 1, several explanations can be explained, namely, the Guidelines for Professional Educator Development are always maximized in the form of team teaching in learning. The training program is entirely based on management guidelines. So that planning is carried out in a directed manner to achieve the training objectives to develop the desired and well-designed educators. The purpose of planning is carried out carefully in a training program 
which is an effort to improve the quality of learning in the activeness of educators and to increase competency development. Furthermore, planning in the teacher skills training program can be implicated in learning to make learning successful. Supported by research from Mukolwe et al (2017) states that the positive performance obtained from the results of collaboration and designing training for educators will provide positive results on organizational professionalism. The maturity of the activity program will optimize the achievement of educational quality (Fahrudin 2015; Maamarah, 2016; Suharto, 2017; Suhardan, 2014).

This research implies that it can contribute to the development of student resources at Muhammadiyah 1 Jember Elementary School and Al Baitul Amien 1 Jember Elementary School, both in coaching activities or in learning management in the classroom so that the two schools are not only superior and competent in student achievement but the competence of teachers and students.

\section{CONCLUSION}

Based on the research conducted, it can be concluded that the concept of the human resource development program carried out by the Elementary School Muhammadiyah of 1 Jember and the Elementary School Al Baitul Amien of 1 Jember to improve the quality of teacher performance, namely

1. By increasing the abilities, skills, attitudes, and responsibilities of educators ( teachers) to be more effective and efficient,

2. Optimizing human resource development as much as possible by delegating to educators (teachers),

3. Striving to improve education quality by recommending educators (teachers) to take further studies to a higher level.

There is no multi-case study research in improving the performance of students.

\section{ACKNOWLEDGEMENTS}

Researchers are grateful to all parties who have helped research the development of teaching resources, especially the teachers, the leadership and staff of Elementary School Muhammadiyah of 1 Jember and Elementary School Al Baitul Amien of 1 Jember.

\section{REFERENCES}

Amundsen, C., \& Wilson, M. (2012). Are we asking the right questions?: A conceptual review of the educational development literature in higher education. Review of Educational Research, 82(1), 90-126.

Austin, A. E., \& Sorcinelli, M. D. (2013). The future of faculty development: Where are we going?. New Directions for Teaching and Learning, 133, 85-97.

Bair, D. E., \& Bair, M. A. (2011). Paradoxes of online teaching. International Journal for the Scholarship of Teaching E Learning, 5(2), 1-15.

Barth, M., Godemann, J., Rieckmann, M. and Stoltenberg, U. (2007), Developing key competencies for sustainable development in higher education, International Journal of Sustainability in Higher Education, 8(4), 416-430.

Bearman, M., Smith, C. D., Carbone, A., Slade, S., Baik, C., Hughes-Warrington, M., \& Neumann, D. L. (2012). Systematic review methodology in higher education. Higher Education Research $\mathcal{E}$ Development, 31(5), 625-640.

Berryman, T., \& Sauve, L. (2016). Ruling relationships in sustainable development and education for sustainable development, Journal Environment Education, 47, 104-117.

David, N. (2018). Gratitude as an enactment of democratic citizenship education. South African Journal of Higher Education, 28(5), 1513-1524. 
Fahrudin, (2015). Peningkatan kinerja dan pengembangan profesionalitas guru sebagai upaya peningkatan mutu pendidikan di indonesia. Prosiding Seminar Nasional Pendidikan Ekonomi \& Bisnis.

Figueiro, P. S., \& Raufflet, E. (2015). Sustainability in higher education: a systematic review with focus on management education, Journal of Cleaner Production, 106(1), 22-33.

Irmayani, H., Wardiah, D., \& Kristiawan, M. (2018). The strategy of sd pusri in improving educational quality. International Journal of Scientific \& Technology Research, 7(7), 113-121.

Khummaedi., Muhammad., Sunyoto., \& Wijaya, M.B.R. (2010). Kesesuaian program keahlian di sekolah menengah kejuruan dengan kebutuhan tenaga kerja di kabupaten semarang. Jurnal Pendidikan Teknik Mesin, 10(1), 29-35.

Krismiyati. (2017). Pengembangan sumber daya manusia dalam meningkatkan kualitas pendidikan di sd negeri inpres angkasa biak. Jurnal Office, 3(1). 43-50.

Lince, R. (2016). Strategi peningkatan profesionalisme guru dalam menghadapi tantangan di era digital. Prosiding Temu Ilmiah Nasional Guru

Maamarah., Siti., \& Supramono. (2016). Strategi peningkatan mutu dan citra sekolah dasar negeri di ungaran semarang. Jurnal Manajemen Pendidikan ,3(1), 115-130.

Mangkunegara, A.P. (2011). Perencanaan dan pengembangan sumber daya manusia. Rifeka Aditama.

Mukolwe, J. O., Michael, O., Ajowi, O., \& Jack. (2017). Implementation of total quality management in primary schools as a panacea for low academic achievement. European Journal of Research in Social Sciences, 5(5), 54-63.

Nadarajah, S., et al. (2012). The relationship of hr practices and job performance of academicians towards career development in malaysian private higher institutions. Procedia - Social and Behavioral Sciences, 57, $102-118$.

Omebe, C. A. (2014). Human resource management in education: Isues and challenges. British Journal of Education, 2(7), 26-31

Prahani, B. K., Deta, U. A., Yasir, M., Astutik, T., Pandiangan, P., Mahtari, S., \& Mubarok, H. (2020). The Concept of "Kampus Merdeka" in Accordance with Freire's Critical Pedagogy. Studies in Philosophy of Science and Education, 1(1), 21-37.

Saw., \& Watana. (2020). The relationship between teachers' perceptions towards human resource management and school climate at myint-mo education foundation (mef) in myanmar. Scholar : Human Sciences, 12(1), 219-229.

Septi, I. A. Y, (2012). Strategi peningkatan mutu manajemen melalui pengembangan program sekolah. Jurnal Manajemen Pendidikan, 23(5), 159-170.

Setiawan, B. (2020). The Anxiety of Educational Reform and Innovation: Bridging of Top-Down and Bottom-Up Strategies within Practice Educational Reform of Curriculum in Indonesia. Studies in Philosophy of Science and Education, 1(2), 87-96.

Stes, A., Min-Leliveld, M., Gijbels, D., Van, P. P. (2010). The impact of instructional development in higher education: The state-of-the-art of the research. Educational Research Review, 5, 2549.

Suhardan, D. (2014). Supervisi profesional layanan dalam meningkatkan mutu pembelajaran di era otonomi daerah. Alfabeta.

Suharto. (2017). The effect supervision, school culture, and work commitment of job performance Primary School in principal of administrative region II City West Jakarta. Journal of Education Research in Administration and Management, 1(3).

Talan, A., \& Tyagi, R. D. (2020). Sustainability: Fundamentals and applications. Wiley Online Library.

Tam, T. P., S. Catherine. C., \& Jill, Z. (2018). A systematic literature review of faculty development for teacher educators. Higher Education Research \& Development, 37(2), 373-389. 
Tenggala, (2013). Analisis implementasi kebijakan pengelolaan sarana dan prasarana sekolah di SMP Negeri 2 Batu Martinus Tanggela. Jurnal Kebijakan dan Pengembangan Pendidikan, 1 (1), 26-34.

Vosloban, V. I. (2012). The Influence of the Employee's Performance on the company's growth - a managerial perspective. Procedia Economics and Finance, 3, 660-665.

Wijaya, E. Y., Sudjimat, D. A., \& Nyoto, A. (2016). Transformasi pendidikan abad 21 sebagai tuntutan pengembangan sumber daya manusia di era global. Prosiding Seminar Nasional Pendidikan Matematika, 1, 263-278.

Zein, M. S. (2016), profesional development needs of primary efl teachers: perspectives of teachers and teacher educators. Journal Professional Development in Education, 43(2), 293-313.

Zuhro, A. (2015). Total quality management: Capaian kualitas output melalui sistem kontrol mutu sekolah. Cendekia, 9(1), 79-94.

\footnotetext{
Author (s) :

*Muh Burhanudin Harahap (Corresponding Author)

Universitas Negeri Surabaya, Indonesia

Jl. Raya Kampus Unesa, Lidah Wetan, Kec. Lakarsantri, Kota SBY, Jawa Timur 60213 Indonesia

Email: muh.harahap16070976008@mhs.unesa.ac.id
}

Maria Veronika Roesminingsih

Universitas Negeri Surabaya, Indonesia

Jl. Raya Kampus Unesa, Lidah Wetan, Kec. Lakarsantri, Kota SBY, Jawa Timur 60213 Indonesia

Email: roesminingsih@unesa.ac.id

\section{Mudjito}

Universitas Negeri Surabaya, Indonesia

Jl. Raya Kampus Unesa, Lidah Wetan, Kec. Lakarsantri, Kota SBY, Jawa Timur 60213 Indonesia

Email: mudjito@unesa.ac.id 